\title{
Efficacy of Percutaneous Adhesiolysis in the Treatment of Lumbar Post Surgery Syndrome
}

\author{
Laxmaiah Manchikanti, ${ }^{1,}$ Kavita N. Manchikanti, ${ }^{2}$ Christopher G. Gharibo, ${ }^{3}$ and Alan D. Kaye ${ }^{4}$ \\ ${ }^{1}$ Pain Management Center of Paducah, University of Louisville, Louisville, Kentucky, USA \\ 2 Physical Medicine and Rehabilitation, University of Kentucky, Lexington, Kentucky, USA \\ ${ }^{3}$ NYU School of Medicine, NYU Langone-Hospital for Joint Diseases, New York, USA \\ ${ }_{4}$ NYU School of Medicine, NYU Langone-Hospital for Joint \\ ${ }^{*}$ Corresponding author: Laxmaiah Manchikanti, Pain Management Center of Paducah, University of Louisville, P. O. Box: 42003, Louisville, Kentucky, USA. Tel: +270-5548373, \\ Fax: 270-5548987, E-mail: drlm@thepainmd.com
}

Received 2014 December 30; Accepted 2015 February 21

\begin{abstract}
Context: Lumbar post-surgery syndrome is common and often results in chronic, persistent pain and disability, which can lead to multiple interventions. After failure of conservative treatment, either surgical treatment or a nonsurgical modality of treatment such as epidural injections, percutaneous adhesiolysis is often contemplated in managing lumbar post surgery syndrome. Recent guidelines and systematic reviews have reached different conclusions about the level of evidence for the efficacy of epidural injections and percutaneous adhesiolysis in managing lumbar post surgery syndrome. The objective of this systematic review was to determine the efficacy of all 3 percutaneous adhesiolysis anatomical approaches (caudal, interlaminar, and transforaminal) in treating lumbar post-surgery syndrome. Evidence Acquisition: Data Sources: A literature search was performed from 1966 through October 2014 utilizing multiple databases. Study Selection: A systematic review of randomized trials published from 1966 through October 2014 of all types of epidural injections and percutaneous adhesiolysis in managing lumbar post-surgery syndrome was performed including methodological quality assessment utilizing Cochrane review criteria, Interventional Pain Management Techniques-Quality Appraisal of Reliability and Risk of Bias Assessment (IPM-QRB), and grading of evidence using 5 levels of evidence ranging from Level I to Level V. Data Extraction: The search strategy emphasized post-surgery syndrome and related pathologies treated with percutaneous adhesiolysis procedures.

Results: The search criteria yielded 16 manuscripts on percutaneous adhesiolysis assessing post-surgery syndrome. Of these, only 4 randomized trials met inclusion criteria for methodological quality assessment, 3 of them were of high quality; and the fourth manuscript was of low quality. Based on these 3 randomized controlled trials, 2 of them with one-day procedure and one with a 3-day procedure, the level of evidence for the efficacy of percutaneous adhesiolysis is Level II based on best evidence synthesis.

Conclusions: Based on this systematic review, percutaneous adhesiolysis is effective in managing patients with lumbar post-surgery syndrome after the failure of conservative management including fluoroscopically directed epidural injections.
\end{abstract}

Keywords: Post Lumbar Surgery Syndrome, Epidural Fibrosis, Percutaneous Adhesiolysis, Randomized Controlled Trial, Injections, Epidural

\section{Context}

The growing prevalence of spinal pain in the United States and across the globe continues to produce substantial economic impact and strain on health-related quality of life. In an assessment in the US Burden of Disease Collaborators for the United States from 1999 to 2010, it was shown that in 2010 low back pain contributed to most years lived with disability (1). The costs of managing spinal pain in the United States, along with its prevalence, continue to increase, ranging up to $\$ 100$ billion per year, including a wide array of interventions, starting with simple exercises to complex fusions and repeat operations (2-22). Despite various modalities, specifically surgical interventions, disability and economic burden continue to rise across the globe $(1,2,6,7,23)$.

Pain and disability in the lumbar spine following various types of spinal surgery have been hypothesized to be secondary to multiple causes, including epidural fibrosis, sacroiliac joint pain, disc herniation, discogenic pain, spinal stenosis, arachnoiditis, facet joint pain, and inappropriate surgery $(7,24-32)$. The development of postoperative epidural fibrosis is a natural process of healing after surgical laminectomy with development of dense scar tissue adjacent to the dura mater (33). This extradural fibrotic tissue may extend into the vertebral canal and adhere to the dura mater and to nerve roots, causing recurrent symptoms, including radicular pain $(24,25$, $34,35)$. The debate continues with regards to the role of epidural fibrosis as being the major cause of pain after lumbar spine surgery.

Some authors have described a lack of association (2629). Ross et al. (24) described that patients with extensive epidural fibrosis were 3.2 times more likely to experience

Copyright (C) 2016, Iranian Society of Regional Anesthesia and Pain Medicine(ISRAPM). This is an open-access article distributed under the terms of the Creative Commons Attribution-NonCommercial 4.0 International License (http://creativecommons.org/licenses/by-nc/4.0/) which permits copy and redistribute the material just in noncommercial usages, provided the original work is properly cited. 
recurrent radicular pain in the lumbar spine than those with less scarring. In addition, experimental studies have provided electrophysiological evidence of neurologic disturbances caused by peridural scar formation (36). A multitude of other abnormalities, including mechanical tethering of nerve roots secondary to epidural fibrosis in the vertebral canal $(37,38)$, disturbances in blood flow (39) and expression of proinflammatory cytokines causing irritation to the exposed dorsal root ganglion and triggering painful responses, have been described (40). Osteopontin also has been shown to play a major role in the formation of epidural fibrosis and a mark-up dorsal root ganglia response to peridural scarring formation (41). Further evidence also has implicated paraspinal muscle spasms, tail contracture, pain behaviors, tactile allodynia, epidural and perineural scarring, and nerve root adherence $(42,43)$. Additionally, it has been postulated that there may be a final common pathway with all the described etiologies, which results in peripheral and central facilitation potentiated by inflammatory and nerve injury mechanisms $(26,36,39-44)$.

Lumbar surgeries for disc herniation, spinal stenosis, degenerative spondylolisthesis, and internal disc disruption have been increasing at a rapid pace (8-12, 45-47). In fact, statistics show an increase in fusions of $131 \%$ from 1998 to 2008, whereas laminectomies have not shown a significant increase in the same period (8). Thus, lumbar post-surgery syndrome in patients suffering with multiple symptoms continues to increase. A re-operation rate of $9.5 \%$ to $25 \%$ at 4 years has been reported, despite advances in surgical techniques (8-10, 40-47). Patients with lumbar post-surgery syndrome not amenable to conservative management, including fluoroscopically directed epidural injections, have been treated with percutaneous epidural adhesiolysis with efficacy and demonstration of cost utility (7, 41, 48-57).

Multiple systematic reviews and guidelines performed by various groups of authors have reached different conclusions about the level of evidence for the effectiveness of percutaneous adhesiolysis $(7,22,48-51,58)$. Some of the authors opined that percutaneous adhesiolysis is not effective in managing lumbar post-surgery syndrome (22, 49, 51). However, other systematic reviews conducted with appropriate methodology showed efficacy based on randomized trials $(7,48,50)$, while others have been criticized $(2,51,58)$. Thus, the aim of this systematic review is to determine the efficacy of percutaneous adhesiolysis in the lumbar spine, in the treatment of post-surgery syndrome, based on randomized controlled trials.

The objective of this systematic review was to determine the efficacy of all 3 percutaneous adhesiolysis anatomical approaches (caudal, interlaminar, and transforaminal) in treating lumbar post-surgery syndrome.

\section{Evidence Acquisition}

The methodology utilized in this systematic review fol- lowed the widely accepted review process derived from evidence-based systematic reviews and meta-analyses of randomized trials (59-63).

\subsection{Data Sources}

A literature search was performed from 1966 through October 2014 utilizing data from PubMed, Cochrane library, the US National Guideline Clearinghouse (NGC), previous systematic reviews, and cross references.

\subsection{Study Selection}

Only randomized controlled trials were utilized, either placebo- or active-controlled. The true definition of placebo is to inject an inactive substance into an inactive structure. For the purposes of this review, we have utilized an injection of placebo into the epidural space or over the nerve root by any approach as placebo, even though it is an impure placebo (64-68). The trials were eligible if the assessment was performed for lumbar post-surgery syndrome. The duration of symptoms of the trial participants was classified chronic if at least 6 months elapsed after surgery. Any of the studies with disc herniation, radiculitis, stenosis, or discogenic pain without previous surgery were not included in this review.

\subsection{Data Extraction}

The search strategy emphasized post-surgery syndrome and related pathologies treated with percutaneous adhesiolysis procedures. Search terms included lumbar post-surgery syndrome, epidural fibrosis, or lumbar postlaminectomy syndrome, failed back surgery syndrome, adhesions, adhesiolysis, epiduroscopy, hypertonic saline, epidural neuroplasty and epidural scar tissue. Search terminology was as follows:

(((((failed back surgery syndrome) or epidural fibrosis) OR lumbar post-laminectomy syndrome) OR post lumbar surgery syndrome) OR lumbar post-surgery syndrome) and $(((((()(($ epidural scar tissue) $)$ OR epidural adhesions $)$ OR hypertonic saline) OR epidural neuroplasty) OR lysis of adhesions) OR epiduroscopy) OR epidural adhesiolysis) OR adhesiolysis) OR spinal adhesions) OR percutaneous adhesiolysis).

\subsection{Outcomes}

All studies providing appropriate management and with outcome evaluations of 6 months or longer and statistical evaluations were reviewed.

The primary outcome measure was pain relief. The secondary outcome measure was functional status improvement.

Summary measures included 50\% or more reduction in pain in at least $50 \%$ of the patients or at least a 3-point decrease in pain scores with an increase in functional status and a relative risk of adverse events including side effects. 


\subsection{Methodological Quality}

The quality of each individual article used in this analysis was assessed by Cochrane review criteria for randomized trials (60) and Interventional Pain Management Techniques-Quality Appraisal of Reliability and Risk of Bias Assessment (IPM-QRB) criteria (61). Only randomized trials meeting the inclusion criteria with at least 4 of 12 Cochrane review criteria or 16 of 48 of IPM-QRB criteria were utilized for analysis. Meta-analysis was considered if more than 2 randomized trials were homogeneous initially with clinical assessment followed by meta-analysis. At least 2 of the review authors independently, in an unblinded standardized manner, performed each search and methodological quality assessment. The primary authors of manuscripts were not involved in the methodological quality assessment. All searches were combined to obtain a unified strategy. Any disagreements between reviewers were resolved by a third author and consensus.

\subsection{Analysis of Evidence}

The analysis of evidence was conducted based on the qualitative level of evidence utilizing a modified approach to grading of evidence as shown in Table 1 (62). This was developed from multiple previously utilized grading schemata, most importantly Cochrane reviews and the US Preventive Services Task Force (USPSTF) (7, 63, 69).

Trials were judged to be positive if the injection therapy was clinically relevant and effective, either with a placebo control or active control, with a statistically significant difference in effect for the primary outcome measure at the conventional 5\% level. Any improvement of less than 6 months was considered as short-term and 6 months or longer was considered as long-term. Furthermore, the outcomes were judged at the reference point with positive or negative results reported at 3 months, 6 months, and one year.

\section{Results}

Figure 1 shows a flow diagram of the study selection as recommended by Preferred Reporting Items for Systematic Reviews and Meta-Analyses (PRISMA) (59).

Overall, there were 16 manuscripts for consideration (52-57, 70-79). Of these, 4 trials met the inclusion criteria for methodological quality assessment (52, 54, 55, 76). The remaining trials were excluded due to being nonrandomized or assessing various aspects of outcome parameters rather than efficacy. There were no trials utilizing interlaminar or transforaminal approaches.

\subsection{Methodological Quality Assessment}

The methodological quality assessment of randomized controlled trials is presented in Tables 2 and 3 for randomized trials of percutaneous adhesiolysis.

Among the 4 trials assessed for methodologic quality, there were 3 high-quality trials utilizing Cochrane review criteria as well as IPM-QRB criteria $(52,54,55)$. One study (76) was of low quality by Cochrane review criteria and IPM-QRB criteria and was excluded.

\subsection{Study Characteristics}

Study characteristics of the 3 included trials $(52,54,55)$ are shown in Table 4 . Of the 3 trials, 2 were performed by Manchikanti et al. $(52,55)$. The first trial $(55)$ was published in 2004 where a total of 75 patients were divided into 3 groups: Group I with 25 patients randomized to a caudal epidural group with catheterization up to S3 with no adhesiolysis; Group II with 25 patients with adhesiolysis, however, without an injection of hypertonic saline, instead with an injection of $0.9 \%$ normal saline; and Group III with 25 patients receiving adhesiolysis, with injection of hypertonic saline. All 3 groups of patients received steroids. Outcome measures were utilized with significant pain relief defined as average relief of $50 \%$ or greater. Functional status was assessed with the Oswestry Disability Index (ODI). Results showed significant improvement in patients in Groups II and III at 2 months, 6 months, and 12 months compared to baseline measurements, as well as compared to Group I who did not receive adhesiolysis.

Table 1. Grading and Synthesis of Best Evidence by Qualitative Analysis a

\begin{tabular}{|c|c|}
\hline Levels & Description \\
\hline Level I & Evidence obtained from multiple relevant high quality randomized controlled trials \\
\hline Level II & $\begin{array}{l}\text { Evidence obtained from at least one relevant high quality randomized controlled trial or multiple relevant moderate } \\
\text { or low quality randomized controlled trials }\end{array}$ \\
\hline Level III & $\begin{array}{l}\text { Evidence obtained from at least one relevant moderate or low quality randomized controlled trial with multiple } \\
\text { relevant observational studies or Evidence obtained from at least one relevant high quality non-randomized trial or } \\
\text { observational study with multiple moderate or low quality observational studies }\end{array}$ \\
\hline Level IV & Evidence obtained from multiple moderate or low quality relevant observational studies \\
\hline Level V & Opinion or consensus of large group of clinicians and/or scientists \\
\hline
\end{tabular}

a Adapted and Modified from: Manchikanti L, Falco FJE, Benyamin RM, Kaye AD, Boswell MV, Hirsch JA. A modified approach to grading of evidence. Pain Physician. 2014; 17: E319 - 25 (62). 


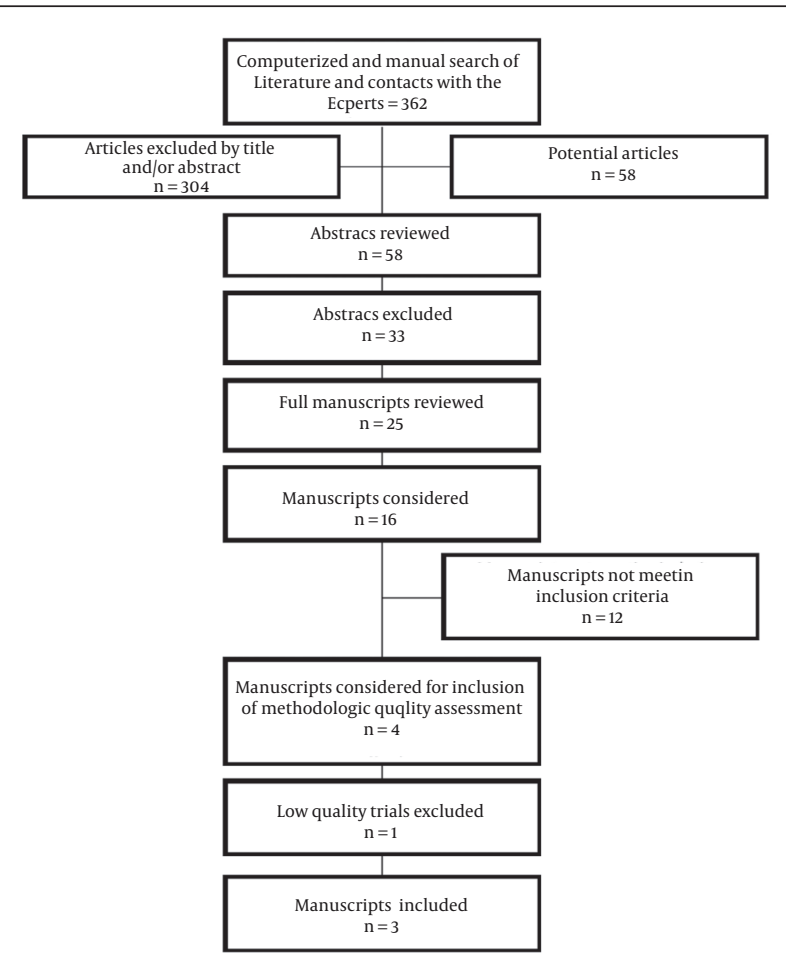

Figure 1. Flow Diagram Illustrating Published Literature Evaluating Percutaneous Adhesiolysis in Lumbar Post-Surgery Syndrome
Even though patients in Group I achieved improvement, the significant improvement lasted for less than 3 months and at one month some patients showed significant improvement in Group I. At 3 months, 6 months, and 12 months, the improvement in Groups II and III was $64 \%$ and $72 \%, 60 \%$ and $72 \%$, and $60 \%$ and $72 \%$. Patients received 3 to 4 procedures per year. This was the first trial conducted utilizing a control group. The study has been criticized for the lack of placebo effect with caudal epidural injections (22). Considering that these patients had already failed fluoroscopically directed caudal epidural injections, which was part of the inclusion criteria, along with failure of conservative management, it is not surprising that none of the patients had any significant relief lasting up to 3 months. They did show reductions in their pain scores, as well as disability scores. Additionally, there were a substantial number of patients who withdrew early in the treatment phase in the control group. Only one-fourth of the patients were included through the end of the study. Thus, inappropriate interpretations have led to the impressions that it was a 3 month study even though the majority of the patients were still participating in the trial until 6 months. In the control group an intention-to-treat analysis was utilized. Methodological quality assessment has taken into consideration the withdrawals of greater than $20 \%$ with an assigned score of "0".

Table 2. Methodological Quality Assessment of Randomized Trials of Epidural Injections and Percutaneous Adhesiolysis in Post Lumbar Surgery Syndrome a,b

\begin{tabular}{|c|c|c|c|c|}
\hline & $\begin{array}{l}\text { Manchikanti } \\
\text { et al.(52) }\end{array}$ & $\begin{array}{l}\text { Heavner } \\
\text { et al. }(54)\end{array}$ & $\begin{array}{l}\text { Manchikanti } \\
\text { et al.(55) }\end{array}$ & $\begin{array}{l}\text { Manchikanti } \\
\text { et al. (76) }\end{array}$ \\
\hline Randomization adequate & $\mathrm{Y}$ & $\mathrm{Y}$ & $\mathrm{Y}$ & $\mathrm{N}$ \\
\hline Concealed treatment allocation & $\mathrm{Y}$ & $\mathrm{Y}$ & $\mathrm{Y}$ & $\mathrm{N}$ \\
\hline Patient blinded & $\mathrm{Y}$ & $\mathrm{Y}$ & $\mathrm{Y}$ & $\mathrm{N}$ \\
\hline Care provider blinded & $\mathrm{N}$ & $\mathrm{N}$ & $\mathrm{N}$ & $\mathrm{N}$ \\
\hline Outcome assessor blinded & $\mathrm{N}$ & $\mathrm{Y}$ & $\mathrm{N}$ & $\mathrm{N}$ \\
\hline Drop-out rate described & $\mathrm{N}$ & $\mathrm{N}$ & $\mathrm{N}$ & $\mathrm{N}$ \\
\hline All randomized participants analyzed in the group & $\mathrm{Y}$ & $\mathrm{N}$ & $\mathrm{Y}$ & $\mathrm{Y}$ \\
\hline Reports of the study free of suggestion of selective outcome reporting & $\mathrm{Y}$ & $\mathrm{Y}$ & $\mathrm{Y}$ & $\mathrm{Y}$ \\
\hline $\begin{array}{l}\text { Groups similar at baseline regarding most important prognostic } \\
\text { indicators }\end{array}$ & $\mathrm{Y}$ & $\mathrm{Y}$ & $\mathrm{Y}$ & $\mathrm{N}$ \\
\hline Co-interventions avoided or similar & Y & $\mathrm{Y}$ & Y & $\mathrm{N}$ \\
\hline Compliance acceptable in all groups & $\mathrm{Y}$ & $\mathrm{Y}$ & $\mathrm{Y}$ & $\mathrm{N}$ \\
\hline Time of outcome assessment in all groups similar & $\mathrm{Y}$ & $\mathrm{Y}$ & Y & $\mathrm{Y}$ \\
\hline Score & $9 / 12$ & $9 / 12$ & $9 / 12$ & $3 / 12$ \\
\hline
\end{tabular}

a Source: Furlan AD, Pennick V, Bombardier C, van Tulder Ml; Editorial Board, Cochrane Back Review Group. 2009 updated method guidelines for systematic reviews in the Cochrane Back Review Group. Spine (Phila Pa 1976). 2009; 34 (18):1929 - 41)(60).

b Abbreviations: $\mathrm{N}=\mathrm{No}$; $\mathrm{U}=$ Unclear; $\mathrm{Y}=$ Yes. 
Table 3. Methodological Quality Assessment of Randomized Trials of Interventional Pain Management Utilizing Interventional Pain Management Techniques-Quality Appraisal of Reliability and Risk of Bias Assessment (IPM-QRB) ${ }^{\mathrm{a}}$

\begin{tabular}{lcccc}
\hline Variables & $\begin{array}{c}\text { Manchikanti } \\
\text { et al.(52) }\end{array}$ & $\begin{array}{c}\text { Heavner et } \\
\text { al.(54) }\end{array}$ & $\begin{array}{c}\text { Manchikanti } \\
\text { et al.(55) }\end{array}$ & $\begin{array}{c}\text { Manchikanti } \\
\text { et al. (76) }\end{array}$ \\
\hline
\end{tabular}

\section{Consort or Spirit}

Trial Design Guidance and Reporting

3

2

2

0

\section{Design Factors}

\begin{tabular}{|c|c|c|c|c|}
\hline Type and Design of Trial & 2 & 2 & 2 & 0 \\
\hline Setting/Physician & 2 & 2 & 2 & 2 \\
\hline Imaging & 3 & 3 & 3 & 0 \\
\hline Sample Size & 3 & 2 & 2 & 0 \\
\hline Statistical Methodology & 1 & 1 & 1 & 1 \\
\hline
\end{tabular}

\section{Patient Factors}

\begin{tabular}{|c|c|c|c|c|}
\hline Inclusiveness of Population & 2 & 2 & 2 & 2 \\
\hline Duration of Pain & 2 & 2 & 2 & 2 \\
\hline Previous Treatments & 2 & 2 & 2 & 2 \\
\hline Duration of Follow-up with Appropriate Interventions & 3 & 3 & 3 & 2 \\
\hline \multicolumn{5}{|l|}{ IV. Outcomes } \\
\hline Outcomes Assessment Criteria for Significant Improvement & 4 & 2 & 4 & 2 \\
\hline Analysis of all Randomized Participants in the Groups & 1 & 0 & 1 & 0 \\
\hline Description of Drop Out Rate & 0 & 0 & 0 & 0 \\
\hline $\begin{array}{l}\text { Similarity of Groups at Baseline for Important Prognostic } \\
\text { Indicators }\end{array}$ & 2 & 1 & 2 & 0 \\
\hline Role of Co-Interventions & 1 & 1 & 1 & 0 \\
\hline
\end{tabular}

\section{Randomization}

Method of Randomization

2

VI. Allocation Concealment

Concealed Treatment Allocation

2

2

2

0

\section{Blinding}

\begin{tabular}{|c|c|c|c|c|}
\hline Patient Blinding & 1 & 1 & 1 & 0 \\
\hline Care Provider Blinding & 0 & 1 & 0 & 0 \\
\hline Outcome Assessor Blinding & 0 & 1 & 1 & 0 \\
\hline \multicolumn{5}{|l|}{ VIII. Conflicts OF Interest } \\
\hline Funding and Sponsorship & 2 & 2 & 2 & 0 \\
\hline Conflicts of Interest & 3 & 3 & 3 & 0 \\
\hline Total & 41 & 37 & 40 & 13 \\
\hline
\end{tabular}

a Source: Manchikanti L, Hirsch JA, Cohen SP, Heavener JE, Falco FJE, Diwan S, et al. Assessment of methodologic quality of randomized trials of interventional techniques: Development of an interventional pain management specific instrument. Pain Physician. 2014; 17 (3): E263-90 (61). 
Manchikanti L et al.

Table 4. Description of Study Characteristics of Randomized Epidural Trials Assessing the Efficacy of Percutaneous Adhesiolysis in Lumbar Post-Surgery Syndrome ${ }^{\text {a }}$

\begin{tabular}{|c|c|c|c|c|c|c|c|c|}
\hline \multirow{2}{*}{$\begin{array}{l}\text { Study Characteristics } \\
\text { Methodological } \\
\text { Quality Scoring }\end{array}$} & \multirow{2}{*}{$\begin{array}{l}\text { Participants/ } \\
\text { Interventions }\end{array}$} & \multirow[t]{2}{*}{ Outcome Measures } & \multicolumn{4}{|c|}{ Pain Relief and Function } & \multirow[t]{2}{*}{ Results } & \multirow[t]{2}{*}{ Comment(s) } \\
\hline & & & $3 \mathrm{mo}$ & $6 \mathrm{mo}$ & $12 \mathrm{mo}$ & $2 y$ & & \\
\hline $\begin{array}{l}\text { Manchikanti et al. } \\
\text { (52) RA, AC; quality } \\
\text { scores: cochrane = } \\
\text { 9/12; IPM-QRB =_41/48 }\end{array}$ & $\begin{array}{c}\text { 120; } 60 \text { adhesiolysis; } \\
60 \text { caudal epidural; } \\
\text { steroid }\end{array}$ & $\begin{array}{c}\text { NRS, ODI, } \\
\text { employment status, } \\
\text { opioid intake. A } \\
\text { significant reduction } \\
\text { was } 50 \% \text { for NRS and } \\
40 \% \text { for ODI. }\end{array}$ & $\begin{array}{l}\text { Caudal } \\
\quad=23 \% ; \\
\text { Adhesiolysis } \\
\quad=78 \%\end{array}$ & $\begin{array}{l}\text { Caudal }=7 \% \\
\text { Adhesiolysis } \\
=73 \%\end{array}$ & $\begin{array}{l}\text { Caudal =5\%; } \\
\text { Adhesiolysis } \\
\quad=70 \%\end{array}$ & $\begin{array}{l}\text { Caudal = } \\
5 \% \text {; Adhe- } \\
\text { siolysis = } \\
82 \%\end{array}$ & $\begin{array}{l}73 \% \text { of adhesiolysis } \\
\text { group had }>50 \% \\
\text { relief at } 12 \text { months; } \\
12 \% \text { of caudal group } \\
\text { did. } 3 \text { - } 4 \text { adhesioly- } \\
\text { sis procedures/year }\end{array}$ & $\begin{array}{l}\text { High quality } \\
\text { trial showing } \\
\text { good } \\
\text { evidence of } \\
\text { effectiveness. }\end{array}$ \\
\hline $\begin{array}{l}\text { Heavner et al. (54); } \\
\text { RA, AC; quality } \\
\text { scores: Cochrane = } \\
\text { 9/12; IPM-QRB = 37/48 }\end{array}$ & $\begin{array}{l}\text { 59;17 Group A: } \\
\text { hyaluronidase } \\
\text { and hypertonic } \\
\text { saline; } 15 \text { Group B: } \\
\text { hypertonic saline; } \\
\text { 17 Group C: isotonic } \\
\text { saline; } 10 \text { Group D: } \\
\text { hyaluronidase and } \\
\text { isotonic saline }\end{array}$ & $\begin{array}{c}\text { VAS, MPQ; VAS } \\
\text { rated mild }(0-29) \text {, } \\
\text { moderate }(30-54) \\
\text { or severe }(55-100) ; \\
\text { Improvement was } \\
\text { a10-point change } \\
\text { in VAS. }\end{array}$ & $\begin{array}{c}40 \%-50 \% \\
\text { of patients } \\
\text { improved }\end{array}$ & $\begin{array}{l}50-70 \% \\
\text { improvement } \\
\text { in } 3 \text { groups } \\
\text { with } 20 \% \text { in } \\
\text { normal saline }\end{array}$ & NA & NA & $\begin{array}{c}\text { Significant } \\
\text { improvement was } \\
\text { seen in } 49 \% \text { at } 3 \\
\text { months, } 43 \% \text { at } 6 \\
\text { months, and } 49 \% \text { at } \\
12 \text { months. }\end{array}$ & $\begin{array}{l}\text { High quality } \\
\text { trial with } \\
\text { effectiveness } \\
\text { demonstrated } \\
\text { with } \\
\text { adhesiolysis. }\end{array}$ \\
\hline $\begin{array}{l}\text { Manchikanti et al. } \\
\text { (55); RA, AC; quality } \\
\text { scores: Cochrane = } \\
\text { 9/12; IPM-QRB = 40/48 }\end{array}$ & $\begin{array}{c}75 ; 25 \text { caudal } \\
\text { epidural steroid } \\
\text { injection; } 25 \text { 1-day } \\
\text { adhesiolysis with } \\
\text { normal saline; } 25 \\
\text { 1-day adhesiolysis } \\
\text { with hypertonic } \\
\text { saline }\end{array}$ & $\begin{array}{l}\text { VAS, ODI, work status, } \\
\text { opioid intake, ROM, } \\
\text { and psychological } \\
\text { evaluation using P-3. } \\
\text { Significant pain relief } \\
\text { was }>50 \% \text { relief. }\end{array}$ & $0 \% ; 64 \% ; 72 \%$ & $0 \% ; 60 \% ; 72 \%$ & $0 \% ; 60 \% ; 72 \%$ & NA & $\begin{array}{c}72 \% \text { of hypertonic } \\
\text { saline and } 60 \% \\
\text { of normal saline } \\
\text { patients had }>50 \% \\
\text { relief at } 12 \text { months, } \\
\text { versus } 0 \% \text { of caudal } \\
\text { injections. }\end{array}$ & $\begin{array}{l}\text { High quality } \\
\text { large trial } \\
\text { demonstrating } \\
\text { efficacy of } \\
\text { adhesiolysis } \\
\text { with 2-year } \\
\text { follow-up and } \\
\text { cost utility [57]. }\end{array}$ \\
\hline
\end{tabular}

a Abbreviations: AC = Active Control; MPQ = McGill Pain Questionnaire; NRS = Numeric Rating Scale; ODI = Oswestry Disability Index; P-3 = Pain Patient Profile; RA = Randomized; ROM = range of motion.

The second trial by Manchikanti et al. (52) also studied the role of percutaneous adhesiolysis compared with caudal epidural injections. They randomized 120 patients into 2 groups with a control group of 60 patients receiving caudal epidural injections with catheterization up to S3 with injection of local anesthetic, betamethasone, and $0.9 \%$ sodium chloride solution. In contrast, the intervention group of 60 patients received percutaneous adhesiolysis, followed by injection of $10 \%$ hypertonic sodium chloride solution, and nonparticulate betamethasone. Robust outcome measures were utilized with a followup lasting up to 24 months with the primary outcome defined as $50 \%$ improvement in pain and ODI scores. The treatments were repeated as pain returned and disability ensued. Overall, patients received 6 to 7 procedures over a period of 2 years in Group II with approximately 78 weeks of relief out of 104 weeks. In this trial, significant improvement was seen in $82 \%$ of patients at 2 year follow-up in the intervention group compared to $5 \%$ in the control group receiving caudal epidural injections. In contrast to the previous trial (55), in this trial, $23 \%$ of the patients showed significant improvement at 3 months, $7 \%$ at 6 months, and $5 \%$ at 12 months and 24 months. Considering the protocol and the design of the trial, the majority of the patients (62\%) were unblinded at the end of one year in the control group, whereas only $3 \%$ were unblinded in the treatment group. However, an appropriate intent-to- treat analysis was performed. The trial may be criticized for not using a placebo group; however, a placebo group is extremely difficult in interventional pain trials. Consequently, the control group with caudal epidural injections seemed to be the most appropriate. Methodological quality assessment has taken into consideration the issue related to withdrawals greater than $20 \%$.

The third trial by Heavner et al.(54)included 59 patients assigned randomly into 4 treatment groups: Group A with 17 patients received hyaluronidase and hypertonic saline, Group B with 15 patents received hypertonic saline, Group C with 17 patients received isotonic saline, and Group D with 10 patients received hyaluronidase and isotonic saline. They concluded that percutaneous epidural neuroplasty, as part of an overall pain management strategy, reduced pain in at least $25 \%$ or more of patients with radiculopathy plus low back pain refractory to conventional therapies.

Compared to trials by Manchikanti et al. $(52,55)$ which were one-day procedures, Heavner et al. (54) published the trial in 1999 and utilized a 3-day protocol. The study has been criticized for its lack of a control group with all patients undergoing adhesiolysis even though one group received isotonic saline instead of hypertonic saline or hyaluronidase. The results showed a lack of significant improvement with the combination of hypertonic saline and hyaluronidase. However, patients 
receiving either hypertonic saline, normal saline, or hyaluronidase faired equally. Overall, $83 \%$ of the patients showed some improvement; however, significant improvement was seen in $49 \%$ at 3 months, $43 \%$ at 6 months, and $49 \%$ at 12 months. Any deficiencies in this trial were taken into consideration during methodological quality assessment.

\subsection{Meta-Analysis}

Three included trials were considered for meta-analysis. There was no homogeneity among the trials. Hence, a meta-analysis was not feasible.

\subsection{Analysis of Evidence}

The results of randomized trials of the efficacy of epidural injections and percutaneous adhesiolysis are shown in Table 4. Based on the qualitative best evidence synthesis and based on 3 relevant high quality, randomized controlled trials, the evidence for percutaneous adhesiolysis in managing lumbar post-surgery syndrome is Level II.

\section{Conclusions}

This systematic review of randomized controlled trials of percutaneous adhesiolysis in managing lumbar postsurgery syndrome showed evidence of Level II based on 3 relevant high quality randomized controlled trials (52, $54,55)$ showing the efficacy of percutaneous adhesiolysis for long-term improvement. All the patients included in these trials suffered from chronic low back pain after surgical interventions. After the failure of multiple modalities of conservative management, including fluoroscopically directed epidural injections, the trials were conducted appropriately and were shown to be of high quality based on Cochrane review criteria as well as IPMQRB criteria. These trials showed improvement in pain and functional status.

The evidence in this systematic review, while similar to some systematic reviews previously published (7, 48), does not correlate with other reviews $(22,49$, 51). The systematic review by Helm et al. (48) was performed appropriately and showed the efficacy of adhesiolysis. However, other reviews were mostly of either a narrative nature or utilized inappropriate methodology $(49,51)$. These reviews have been criticized for their methodology $(22,51,58)$. Chou and Huffman (22) misinterpreted the results and provided inaccurate analysis, and reached inappropriate conclusions (58). In fact, Chou and Huffman (22) not only provided inaccurate data, but also utilized the control group which received caudal epidural injections in this trial to demonstrate the failure of caudal epidural injections which is inappropriate as these patients already had failed caudal epidural injections prior to their inclusion into the adhesiolysis group.

The surgical interventions described in managing post-surgery syndrome have shown only modest results (10-13, 22, 25, 78, 79); however, spinal cord stimulation has shown clinical efficacy and cost effectiveness in multiple trials of post-surgery syndrome $(80,81)$. Caudal epidural injections (82), as well as percutaneous adhesiolysis (57) have shown cost utility in managing lumbar post-surgery syndrome. Cost utility in post-surgery syndrome was assessed (57) based on a randomized trial (54) utilized in this assessment which showed cost utility at \$2,650 per Quality-Adjusted Life-Year (QALY). Thus, percutaneous adhesiolysis is a viable option in managing post-surgery syndrome patients after the failure of conservative management including caudal epidural injections prior to proceeding with spinal cord stimulation or repeat surgery.

Percutaneous adhesiolysis, a procedure designed to lyse epidural scarring in patients with persistent low back and leg pain due to lumbar post-surgery syndrome, has evolved over the years with a changing definition and concepts. It was originally described as a 3-day procedure using hypertonic saline, local anesthetic, steroid, and hyaluronidase administered using a reinforceable catheter. Heavner et al. (54) showed that neither hypertonic saline nor hyaluronidase was critical for a successful outcome. Subsequently, Manchikanti et al. (55) studied the efficacy of one-day percutaneous adhesiolysis. Two $(52,55)$ of the 3 trials $(52,54,55)$ included in this assessment were based on one-day adhesiolysis, whereas one trial (54) was based on 3-day percutaneous adhesiolysis. Patients received approximately 3 to 4 interventions during one year and 6 interventions during a 2-year period with one-day adhesiolysis whereas with the 3-day adhesiolysis by Heavner et al. (54), only one procedure was carried out. Consequently, the results must be interpreted cautiously in comparing these trials.

The major issues related to conducting research pertaining to percutaneous adhesiolysis, along with other interventional techniques, involve the control group, placebo effect, and nocebo effects. Placebo control neural blockade is not only unrealistic, but also provides inaccurate results. Further, some have interpreted any local anesthetic injection yielding similar results as steroids as placebo. The evolving literature on placebo, nocebo, and the effect of inactive solutions when injected into active structures has been extensively discussed in recent years (64-68). Methodologists tend to focus on the difference between 2 groups, ignoring equivalency trials and non-inferiority trials, as well as the basis of comparative effectiveness research, which essentially evaluates the differences or similarities between 2 treatments. Thus, conclusions that neither treatment works is inappropriate. Instead, it should be that both treatments work and there is no difference. In fact, in a recent widely publicized trial by Friedly et al. (83) assessing outcomes of interlaminar and transforaminal epidural injections in managing spinal stenosis, the authors misinterpreted the evidence by assigning 2 dif- 
ferent levels of evidence synthesis for combined analysis with a $P$ value of 0.05 and changing it to a $P$ value of 0.025 for interlaminar and transforaminal epidural injections when analyzed separately (84). In essence, this trial showed the efficacy of local anesthetic, as well as steroids, for 6 weeks following one procedure in the majority of the patients, which is appropriate as the effect of epidural injections with the first injection lasts approximately 3 weeks on average $(7,85-87)$. While the design of placebo is an extremely difficult venture in interventional pain management, specifically with percutaneous adhesiolysis, recently 2 appropriately designed trials have been published $(67,68)$.

Percutaneous adhesiolysis involves multiple components of treatment with adhesiolysis, injection of local anesthetic, steroid, hypertonic sodium chloride solution, and hyaluronidase. All the components have not been applied in all the trials. All the components have not been well studied separately. These components provide different mechanisms of action and result in variable outcomes in chronic, persistent recalcitrant pain secondary to post surgery syndrome. Corticosteroids have been shown to be anti-inflammatory, along with local anesthetics $(7,52,54,55,85-87)$. The hypertonic saline utilized in percutaneous adhesiolysis has been shown to attenuate the transmitter release from an exposed neuromuscular junction $(7,52,54,55,85-87)$. Other mechanisms also included $\mathrm{C}$ fiber blockade in cat dorsal rootlets with an increased concentration of chloride ion, decrease of the spinal cord water content, and depressed lateral column evoked ventral root response change in the volume due to outflow of water across the membrane and ionic concentration changes, reduction and swelling are by osmotically induced fluid shifts, reducing pressure on the nerve, and reduce local anesthetic effect of hypertonic solution (67).

The results of this systematic review are clinically oriented and may be applied in interventional pain management practices utilizing appropriate evaluation. Future implications for research should include a clear case definition with consistent inclusion and exclusion criteria; technical considerations; frequency, type, and volume of injectate; appropriate design and outcome measures; and compliance with CONSORT guidelines.

In conclusion, this systematic review provides practical evidence for management of an extremely difficult problem with recalcitrant low back and lower extremity pain secondary to lumbar post-surgery syndrome with 3 relevant high-quality randomized controlled trials providing qualitative evidence of Level II.

\section{Acknowledgments}

The authors wish to thank Vidyasagar Pampati, MSc, for statistical assistance; Tom Prigge, MA, and Laurie Swick, BS, for manuscript review; and Tonie M. Hatton and Diane E. Neihoff, transcriptionists, for their assistance in preparation of this manuscript.

\section{Footnote}

Authors' Contribution:Study concept and design: Laxmaiah Manchikanti, Kavita N. Manchikanti, Christopher G. Gharibo, Alan D. Kaye. Data collection: Laxmaiah Manchikanti, VP, Kavita N. Manchikanti, Christopher G. Gharibo, Alan D. Kaye. Data analysis and manuscript preparation: Laxmaiah Manchikanti, Kavita N. Manchikanti, Christopher G. Gharibo, Alan D. Kaye. Critical revision: Laxmaiah Manchikanti, Kavita N. Manchikanti, Christopher G. Gharibo, Alan D. Kaye.

\section{References}

1. Murray CJ, Atkinson C, Bhalla K, Birbeck G, Burstein R, Chou D, et al. The state of US health, 1990-2010: burden of diseases, injuries, and risk factors. JAMA. 2013;310(6):591-608. doi: 10.1001/ jama.2013.13805. [PubMed:23842577]

2. Gaskin DJ, Richard P. The economic costs of pain in the United States. J Pain. 2012;13(8):715-24. doi: 10.1016/j.jpain.2012.03.009. [PubMed: 22607834]

3. Freburger JK, Holmes GM, Agans RP, Jackman AM, Darter JD, Wallace AS, et al. The rising prevalence of chronic low back pain. Arch Intern Med. 2009;169(3):251-8. doi: 10.1001/archinternmed.2008.543. [PubMed:19204216]

4. Hoy D, Brooks P, Blyth F, Buchbinder R. The Epidemiology of low back pain. Best Pract Res Clin Rheumatol. 2010;24(6):769-81. doi 10.1016/j.berh.2010.10.002. [PubMed:21665125]

5. Martin BI, Turner JA, Mirza SK, Lee MJ, Comstock BA, Deyo RA. Trends in health care expenditures, utilization, and health status among US adults with spine problems, 1997-2006. Spine (Phila Pa 1976). 2009;34(19):2077-84. doi: 10.1097/BRS.ob013e3181b1fad1. [PubMed: 19675510]

6. Manchikanti L, Boswell MV, Hirsch JA. Lessons learned in the abuse of pain-relief medication: a focus on healthcare costs. Expert Rev Neurother. 2013;13(5):527-43. doi: 10.1586/ern.13.33. [PubMed: 23621310]

7. Manchikanti L, Abdi S, Atluri S, Benyamin RM, Boswell MV, Buenaventura RM, et al. An update of comprehensive evidencebased guidelines for interventional techniques in chronic spinal pain. Part II: guidance and recommendations. Pain Physician. 2013;16(2 Suppl):S49-283. [PubMed:23615883]

8. Rajaee SS, Bae HW, Kanim LE, Delamarter RB. Spinal fusion in the United States: analysis of trends from 1998 to 2008. Spine (Phila Pa 1976). 2012;37(1):67-76. doi: 10.1097/BRS.0b013e31820cccfb. [PubMed: 21311399]

9. Bae HW, Rajaee SS, Kanim LE. Nationwide trends in the surgical management of lumbar spinal stenosis. Spine (Phila Pa 1976). 2013;38(11):916-26. doi: 10.1097/BRS.0b013e3182833e7c. [PubMed: 23324922]

10. Kim CH, Chung CK, Park CS, Choi B, Kim MJ, Park BJ. Reoperation rate after surgery for lumbar herniated intervertebral disc disease: nationwide cohort study. Spine (Phila Pa 1976). 2013;38(7):581-90. doi: 10.1097/BRS.0b013e318274f9a7. [PubMed: 23023591]

11. Kovacs FM, Urrútia G, Alarcón JD. Surgery versus conservative treatment for symptomatic lumbar spinal stenosis: a systematic review of randomized controlled trials. Spine. 2011;36(20):E1335-51. [PubMed: 21311394]

12. Jacobs WCH, van Tulder M, Arts M, Rubinstein SM, van Middelkoop M, Ostelo R, et al. Surgery versus conservative management of sciatica due to a lumbar herniated disc: a systematic review. European Spine Journal. 2011;20(4):513-22. [PubMed: 20949289]

13. van Middelkoop M, Rubinstein SM, Kuijpers T, Verhagen AP, Ostelo R, Koes BW, et al. A systematic review on the effectiveness of physical and rehabilitation interventions for chronic nonspecific low back pain. Eur Spine J. 2011;20(1):19-39. doi: 10.1007| s00586-010-1518-3. [PubMed: 20640863]

14. Rubinstein SM, van Middelkoop M, Assendelft WJ, de Boer MR, van Tulder MW. Spinal manipulative therapy for chronic low- 
Manchikanti L et al.

back pain: an update of a Cochrane review. Spine (Phila Pa 1976). 2011;36(13):E825-46. doi: 10.1097/BRS.ob013e3182197fe1. [PubMed: 21593658]

15. Davis MA, Sirovich BE, Weeks WB. Utilization and expenditures on chiropractic care in the United States from 1997 to 2006. Health Serv Res. 2010;45(3):748-61. doi: 10.1111/j.1475-6773.2009.01067.x. [PubMed: 20002763]

16. Fu R, Selph S, McDonagh M, Peterson K, Tiwari A, Chou R, et al Effectiveness and harms of recombinant human bone morphogenetic protein-2 in spine fusion: a systematic review and meta-analysis. Annals of internal medicine. 2013;158(12):890-902. [PubMed: 23778906]

17. Manchikanti L, Pampati V, Falco FJ, Hirsch JA. Growth of spinal interventional pain management techniques: analysis of utilization trends and Medicare expenditures 2000 to 2008. Spine (Phila Pa 1976). 2013;38(2):157-68. doi:10.1097/BRS.ob013e318267f463. [PubMed: 22781007]

18. Manchikanti L, Helm II S, Singh V, Hirsch JA. Accountable interventional pain management: a collaboration among practitioners, patients, payers, and government. Pain Physician. 2013;16(6):E635-70. [PubMed: 24284849]

19. Manchikanti L, Falco FJ, Singh V, Pampati V, Parr AT, Benyamin RM, et al. Utilization of interventional techniques in managing chronic pain in the Medicare population: analysis of growth patterns from 2000 to 2011. Pain Physician. 2012;15(6):E969-82. [PubMed: 23159982]

20. Abbott ZI, Nair KV, Allen RR, Akuthota VR. Utilization characteristics of spinal interventions. Spine J. 2012;12(1):35-43. doi:10.1016/j. spinee.2011.10.005. [PubMed:22138113]

21. Chou R, Huffman L. Guideline for the Use of Chronic Opioid Therapy in Chronic Noncancer Pain: Evidence Review.Glenview, IL: American Pain Society; 2009.

22. Chou R, Huffman L. Guideline for the Evaluation and Management of Low Back Pain: Evidence Review. Glenview, IL: American Pain Society; 2009.

23. U.S. Social Security Administration. Annual statistical report on the Social Security Disability Insurance Program, 2011. 2012. Available from: www.ssa.gov/policy/docs/statcomps/di_asr/2011/ di_asr11.pdf.

24. Ross JS, Robertson JT, Frederickson RCA, Petrie JL, Obuchowski $\mathrm{N}$, Modic MT. Association between peridural scar and recurrent radicular pain after lumbar discectomy: magnetic resonance evaluation. Neurosurgery. 1996;38(4):855-63. [PubMed: 8692415]

25. Fritsch EW, Heisel J, Rupp S. The failed back surgery syndrome: reasons, intraoperative findings, and long-term results: a report of 182 operative treatments. Spine (Phila Pa 1976).1996;21(5):626-33. [PubMed: 8852320]

26. Vogelsang JP, Finkenstaedt M, Vogelsang M, Markakis E. Recurrent pain after lumbar discectomy: the diagnostic value of peridural scar on MRI. Eur Spine J. 1999;8(6):475-9. [PubMed: 10664306]

27. BenDebba M, Augustus van Alphen H, Long DM. Association between peridural scar and activity-related pain after lumbar discectomy. Neurol Res. 1999;21 Suppl 1:S37-42. [PubMed:10214570]

28. Rönnberg K, Lind B, Zoëga B, Gadeholt-Göthlin G, Halldin K, Gellerstedt M, et al. Peridural scar and its relation to clinical outcome: a randomised study on surgically treated lumbar disc herniation patients. European spine journal. 2008;17(12):1714-20. [PubMed:18946688]

29. Almeida DB, Prandini MN, Awamura Y, Vitola ML, Simiao MP, Milano JB, et al. Outcome following lumbar disc surgery: the role of fibrosis. Acta Neurochir(Wien). 2008;150(11):1167-76. doi: 10.1007| s00701-008-0131-2. [PubMed: 18936878]

30. Manchikanti L, Manchukonda R, Pampati V, Damron KS, McManus $C D$. Prevalence of facet joint pain in chronic low back pain in postsurgical patients by controlled comparative local anesthetic blocks. Arch Phys Med Rehabil. 2007;88(4):449-55. doi: 10.1016/j. apmr.2007.01.015. [PubMed: 17398245]

31. DePalma MJ, Ketchum JM, Saullo TR. Etiology of chronic low back pain in patients having undergone lumbar fusion. Pain Med. 2011;12(5):732-9. doi: 10.1111/j.1526-4637.2011.01098.x. [PubMed: 21481166]
32. DePalma MJ, Ketchum JM, Saullo TR, Laplante BL. Is the history of a surgical discectomy related to the source of chronic low back pain? Pain Physician. 2012;15(1):E53-8. [PubMed:22270748]

33. Zeinalizadeh M, Miri SM, Ardalan FA, Maleki F, Zakeri M, Aghajanzadeh E, et al. Reduction of epidural fibrosis and dural adhesions after lamina reconstruction by absorbable cement: an experimental study. Spine J. 2014;14(1):113-8. doi: 10.1016/j. spinee.2013.06.065. [PubMed: 23999230]

34. Bartynski WS, Petropoulou KA. The MR imaging features and clinical correlates in low back pain-related syndromes. Magn Reson Imaging Clin N Am. 2007;15(2):137-54. doi: 10.1016/j. mric.2007.01.010. [PubMed: 17599636]

35. Robertson JT. Role of peridural fibrosis in the failed back: a review. Euro spine $j$ : official publication of the European Spine Society, the European Spinal Deformity Society, and the European Section of the Cervical Spine Research Society. 1996;1:S2-6..

36. Jou IM, Tai TW, Tsai CL, Tsai TM, Yung WS, Jung YC. Spinal somatosensory evoked potential to evaluate neurophysiologic changes associated with postlaminotomy fibrosis: an experimental study. Spine (Phila Pa 1976). 2007;32(19):2111-8. doi:10.1097| BRS.ob013e3181453fa5. [PubMed: 17762813]

37. Alkalay RN, Kim DH, Urry DW, Xu J, Parker TM, Glazer PA. Prevention of postlaminectomy epidural fibrosis using bioelastic materials. Spine (Phila Pa 1976). 2003;28(15):1659-65. doi: 10.1097/01. BRS.0000083161.67605.40. [PubMed:12897488]

38. Ozer AF, Oktenoglu T, Sasani M, Bozkus H, Canbulat N, Karaarslan E, et al. Preserving the ligamentum flavum in lumbar discectomy: a new technique that prevents scar tissue formation in the first 6 months postsurgery. Neurosurgery. 2006;59(1):ONS-126ONS-133. [PubMed:16823322]

39. Cooper RG, Freemont AJ, Hoyland JA, Jenkins JPR, West CGH, Illingworth $\mathrm{KJ}$, et al. Herniated intervertebral disc-associated periradicular fibrosis and vascular abnormalities occur without inflammatory cell infiltration. Spine. 1995;20(5):591-8. [PubMed: 7604329]

40. Schimizzi AL, Massie JB, Murphy M, Perry A, Kim CW, Garfin SR, et al. High-molecular-weight hyaluronan inhibits macrophage proliferation and cytokine release in the early wound of a preclinical postlaminectomy rat model. Spine J. 2006;6(5):550-6. doi:10.1016/j.spinee.2005.12.005. [PubMed:16934726]

41. Brzezicki G, Jankowski R, Blok T, Klimczak A, Szymas J, Huber J, et al. Postlaminectomy osteopontin expression and associated neurophysiological findings in rat peridural scar model. Spine. 2011;36(5):378-85. [PubMed:20838370]

42. Massie JB, Huang B, Malkmus S, Yaksh TL, Kim CW, Garfin SR, et al. A preclinical post laminectomy rat model mimics the human post laminectomy syndrome. J Neurosci Methods.2004;137(2):2839. doi:10.1016/j.jneumeth.2004.02.036. [PubMed:15262072]

43. Haq I, Cruz-Almeida Y, Siqueira EB, Norenberg M, Green BA, Levi AD. Postoperative fibrosis after surgical treatment of the porcine spinal cord: a comparison of dural substitutes. Invited submission from the Joint Section Meeting on Disorders of the Spine and Peripheral Nerves, March 2004. J Neurosurg Spine. 2005;2(1):50-4. doi: 10.3171/spi.2005.2.1.0050. [PubMed:15658126]

44. Harrington JF, Messier AA, Hoffman L, Yu E, Dykhuizen M, Barker K. Physiological and behavioral evidence for focal nociception induced by epidural glutamate infusion in rats. Spine (Phila Pa 1976). 2005;30(6):606-12. [PubMed:15770173]

45. Deyo RA, Martin BI, Kreuter W, Jarvik JG, Angier H, Mirza SK. Revision surgery following operations for lumbar stenosis. Bone Joint Surg Am. 2011;93(21):1979-86. doi: 10.2106/JBJS.J.01292. [PubMed: 22048092]

46. Martin BI, Mirza SK, Flum DR, Wickizer TM, Heagerty PJ, Lenkosk $A F$, et al. Repeat surgery after lumbar decompression for herniated disc: the quality implications of hospital and surgeon variation. Spine J. 2012;12(2):89-97. doi: 10.1016/j.spinee.2011.11.010. [PubMed: 22193055]

47. Phillips FM, Slosar PJ, Youssef JA, Andersson G, Papatheofanis F. Lumbar spine fusion for chronic low back pain due to degenerative disc disease: a systematic review. Spine (Phila Pa 1976). 2013;38(7):E409-22. doi: 10.1097/BRS.ob013e3182877f11. [PubMed: 23334400] 
48. Helm II S, Benyamin RM, Chopra P, Deer TR, Justiz R. Percutaneous adhesiolysis in the management of chronic low back pain in post lumbar surgery syndrome and spinal stenosis: a systematic review. Pain Physician. 2012;15(4):E435-62. [PubMed: 22828693]

49. Lee F, Jamison DE, Hurley RW, Cohen SP. Epidural lysis of adhesions. Korean J Pain. 2014;27(1):3-15. doi: 10.3344/kjp.2014.27.1.3. [PubMed: 24478895]

50. Helm II S, Hayek SM, Colson J, Chopra P, Deer TR, Justiz R, et al. Spinal endoscopic adhesiolysis in post lumbar surgery syndrome: an update of assessment of the evidence. Pain Physician. 2013;16(2 Suppl):SE125-50. [PubMed: 23615889]

51. Jamison DE, Hsu E, Cohen SP. Epidural adhesiolysis: an evidence-based review. J Neurosurg Sci. 2014;58(2):65-76. [PubMed: 24819483]

52. Manchikanti L, Singh V, Cash KA, Pampati V. Assessment of effectiveness of percutaneous adhesiolysis and caudal epidural injections in managing post lumbar surgery syndrome: 2-year followup of a randomized, controlled trial. J Pain Res. 2012;5:597-608. doi:10.2147/[PR.S38999. [PubMed:23293536

53. Choi E, Nahm FS, Lee PB. Evaluation of prognostic predictors of percutaneous adhesiolysis using a Racz catheter for post lumbar surgery syndrome or spinal stenosis. Pain Physician. 2013;16(5):E531-6. [PubMed: 24077203]

54. Heavner JE, Racz GB, Raj P. Percutaneous epidural neuroplasty: prospective evaluation of $0.9 \% \mathrm{NaCl}$ versus $10 \% \mathrm{NaCl}$ with or without hyaluronidase. Reg Anesth Pain Med. 1999;24(3):202-7. [PubMed: 10338168]

55. Manchikanti L, Rivera JJ, Pampati V, Damron KS, McManus CD, Brandon DE, et al. One day lumbar epidural adhesiolysis and hypertonic saline neurolysis in treatment of chronic low back pain: a randomized, double-blind trial. Pain Physician. 2004;7(2):17786. [PubMed:16868590]

56. Yousef A, EL - deen AS, Al - deeb AE. The Role of Adding Hyaluronidase to Fluoroscopically Guided Caudal Steroid and Hypertonic Saline Injection in Patients with Failed Back Surgery Syndrome: A Prospective, Double - Blinded, Randomized Study. Pain Practice. 2010;10(6):548-53. [PubMed: 20412501]

57. Manchikanti L, Helm II S, Pampati V, Racz GB. Cost Utility Analysis of Percutaneous Adhesiolysis in Managing Pain of Post-lumbar Surgery Syndrome and Lumbar Central Spinal Stenosis. Pain Pract. 2014. doi: 10.1111/papr.12195. [PubMed:24666747]

58. Manchikanti L, Datta S, Gupta S, Munglani R, Bryce DA, Ward SP et al. A critical review of the American Pain Society clinical practice guidelines for interventional techniques: part 2. Therapeutic interventions. Pain Physician. 2010;13(4):E215-64. [PubMed: 20648212]

59. Liberati A, Altman DG, Tetzlaff J, Mulrow C, Gøtzsche PC, Ioannidis JPA, et al. The PRISMA statement for reporting systematic reviews and meta-analyses of studies that evaluate health care interventions: explanation and elaboration. Annals of internal medicine. 2009;151(4):W-65-W-94.

60. Furlan AD, Pennick V, Bombardier C, van Tulder M, Editoria Board CBRG. 2009 updated method guidelines for systematic reviews in the Cochrane Back Review Group. Spine (Phila Pa 1976). 2009;34(18):1929-41. doi: 10.1097/BRS.0b013e3181b1c99f. [PubMed: 19680101]

61. Manchikanti L, Hirsch JA, Cohen SP, Heavner JE, Falco FJ, Diwan $\mathrm{S}$, et al. Assessment of methodologic quality of randomized trials of interventional techniques: development of an interventional pain management specific instrument. Pain Physician. 2014;17(3):E263-90. [PubMed: 24850111]

62. Manchikanti L, Falco FJ, Benyamin RM, Kaye AD, Boswell MV, Hirsch JA. A modified approach to grading of evidence. Pain Physician. 2014;17(3):E319-25. [PubMed: 24850113]

63. Manchikanti L, Falco FJ, Singh V, Benyamin RM, Racz GB, Helm I $S$, et al. An update of comprehensive evidence-based guidelines for interventional techniques in chronic spinal pain. Part I: introduction and general considerations. Pain Physician. 2013;16(2 Suppl):S1-48. [PubMed: 23615882]

64. Manchikanti L, Giordano J, Fellows B, Hirsch JA. Placebo and nocebo in interventional pain management: a friend or a foe--or simply foes? Pain Physician. 2011;14(2):E157-75. [PubMed: 21412379]
65. Bingel U, Placebo Competence T. Avoiding nocebo effects to optimize treatment outcome. JAMA. 2014;312(7):693-4. doi: 10.1001/ jama.2014.8342. [PubMed: 25003609]

66. Blease C. The principle of parity: the 'placebo effect' and physician communication. I Med Ethics. 2012;38(4):199-203. doi 10.1136/medethics-2011-100177. [PubMed: 22048851]

67. Ghahreman A, Ferch R, Bogduk N. The efficacy of transforaminal injection of steroids for the treatment of lumbar radicular pain. Pain Med. 2010;11(8):1149-68. doi:10.1111/j.1526-4637.2010.00908.x. [PubMed: 20704666]

68. Gerdesmeyer L, Wagenpfeil S, Birkenmaier C, Veihelmann A Hauschild M, Wagner K, et al. Percutaneous epidural lysis of adhesions in chronic lumbar radicular pain: a randomized, double-blind, placebo-controlled trial. Pain Physician. 2013;16(3):18596. [PubMed: 23703406]

69. Harris RP, Helfand M, Woolf SH, Lohr KN, Mulrow CD, Teutsch SM, et al. Current methods of the US Preventive Services Task Force: a review of the process. Am J Prev Med. 2001;20(3 Suppl):21-35. [PubMed: 11306229]

70. Lee JH, Lee S. Clinical Effectiveness of Percutaneous Adhesiolysis Versus Transforaminal Epidural Steroid Injection in Patients With Postlumbar Surgery Syndrome. Regional anesthesia and pain medicine. 2014;39(3):214-8. [PubMed: 24646624]

71. Choi SS, Joo EY, Hwang BS, Lee JH, Lee G, Suh JH, et al. A novel balloon-inflatable catheter for percutaneous epidural adhesiolysis and decompression. Korean J Pain. 2014;27(2):178-85. doi: 10.3344 kjp.2014.27.2.178. [PubMed: 24748948]

72. Koh WU, Choi SS, Park SY, Joo EY, Kim SH, Lee JD, et al. Transforaminal hypertonic saline for the treatment of lumbar lateral canal stenosis: a double-blinded, randomized, active-control trial. Pain Physician. 2013;16(3):197-211. [PubMed: 23703407]

73. Hwang BY, Ko HS, Suh JH, Shin JW, Leem JG, Lee JD. Clinical experiences of performing transforaminal balloon adhesiolysis in patients with failed back surgery syndrome: two cases report. Korean J Anesthesiol.2014;66(2):169-72. doi:10.4097/kjae.2014.66.2.169. [PubMed: 24624278]

74. Kim JH, Jung HJ, Nahm FS, Lee PB. Does Improvement in Epidurography Following Percutaneous Epidural Neuroplasty Correspond to Patient Outcome? Pain Pract.2014. doi:10.1111/papr.12197. [PubMed: 24750546]

75. Lee JH, Lee SH. Clinical effectiveness of percutaneous adhesiolysis using Navicath for the management of chronic pain due to lumbosacral disc herniation. Pain Physician. 2012;15(3):213-21. [PubMed: 22622905]

76. Manchikanti L, Pampati V, Fellows B, Rivera J, Beyer CD, Damron KS. Role of one day epidural adhesiolysis in management of chronic low back pain: a randomized clinical trial. Pain Physician. 2001;4(2):153-66. [PubMed:16902688]

77. Deyo RA, Mirza SK, Turner JA, Martin BI. Overtreating chronic back pain: time to back off? J Am Board Fam Med. 2009;22(1):62-8. doi:10.3122/jabfm.2009.01.080102. [PubMed:19124635]

78. Tosteson ANA, Skinner JS, Tosteson TD, Lurie JD, Andersson GB, Berven S, et al. The Cost Effectiveness of Surgical Versus Nonoperative Treatment for Lumbar Disc Herniation Over Two Years. Spine. 2008;33(19):2108-15. doi: 10.1097/BRS.ob013e318182e390. [PubMed: 18777603]

79. Tosteson ANA, Lurie JD, Tosteson TD, Skinner JS, Herkowitz H, Albert T, et al. Surgical treatment of spinal stenosis with and without degenerative spondylolisthesis: cost-effectiveness after 2 years. Annals of internal medicine. 2008;149(12):845-53. [PubMed: 19075203]

80. North RB, Kidd D, Shipley J, Taylor RS. Spinal cord stimulation versus reoperation for failed back surgery syndrome: a cost effectiveness and cost utility analysis based on a randomized controlled trial. Neurosurgery. 2007;61(2).

81. Taylor RS, Ryan J, O'Donnell R, Eldabe S, Kumar K, North RB. The cost-effectiveness of spinal cord stimulation in the treatment of failed back surgery syndrome. Clin J Pain. 2010;26(6):463-9. doi: 10.1097/AJP.ob013e3181daccec. [PubMed: 20551721]

82. Manchikanti L, Falco FJ, Pampati V, Cash KA, Benyamin RM, Hirsch JA. Cost utility analysis of caudal epidural injections in the treatment of lumbar disc herniation, axial or discogenic 


\section{Manchikanti L et al.}

low back pain, central spinal stenosis, and post lumbar surgery syndrome. Pain Physician. 2013;16(3):E129-43. [PubMed: 23703415]

83. Friedly JL, Comstock BA, Turner JA, Heagerty PJ, Deyo RA, Sullivan SD, et al. A randomized trial of epidural glucocorticoid injections for spinal stenosis. N Engl J Med. 2014;371(1):11-21. doi: 10.1056/NEJMoa1313265. [PubMed: 24988555]

84. Manchikanti L, Candido KD, Kaye AD, Boswell MV, Benyamin RM, Falco FJ, et al. Randomized trial of epidural injections for spinal stenosis published in the New England Journal of Medicine: further confusion without clarification. Pain Physician. 2014;17(4):E475-88. [PubMed:25054398]

85. Manchikanti L, Cash KA, McManus CD, Pampati V, Fellows B.
Results of 2-year follow-up of a randomized, double-blind, controlled trial of fluoroscopic caudal epidural injections in central spinal stenosis. Pain Physician. 2012;15(5):371-84. [PubMed: 22996849]

86. Manchikanti L, Cash KA, McManus CD, Damron KS, Pampati V, Falco FJ. A randomized, double-blind controlled trial of lumbar interlaminar epidural injections in central spinal stenosis: 2-year follow-up. Pain Physician. 2015;18(1):79-92. [PubMed: 25675062]

87. Manchikanti L, Cash KA, Pampati V, Falco FJ. Transforaminal epidural injections in chronic lumbar disc herniation: a randomized, double-blind, active-control trial. Pain Physician. 2014;17(4):E489-501. [PubMed: 25054399] 